\title{
Application of technology packages to improve seed production and profitability of garlic (Allium sativum L.)
}

\author{
Titin Sugianti, Lia Hadiawati, Moh. Nazam*, and A. Suriadi \\ Assessment Institute for Agricultural Technology West Nusa Tenggara, Jl. Raya Peninjauan \\ Narmada, Lombok Barat NTB Indonesia
}

\begin{abstract}
The quality seed production is a main strategy to improve national garlic development. The study aim was to evaluate productivity and profitability of garlic seed production technology packages in Sembalun, East Lombok, Indonesia. There were three technology packages tested namely, the national recommendation package (A); site-specific recommendation package (B); and farmer practices (C) which was laid out in a randomized completely block design with 6 replications. The results showed that the fresh bulbs of the Sangga Sembalun garlic variety was significantly higher at packages A and B with $42.19 \mathrm{tha}^{-1}$ and $38.99 \mathrm{t} \mathrm{ha}^{-1}$ respectively, than that of package $\mathrm{C}$ (yield of $31.24 \mathrm{t} \mathrm{ha}^{-1}$ ). The pattern was consistent after seed stored for 12 weeks. Garlic seed production was profitable with $\mathrm{R} / \mathrm{C}$ ratio values of 3.39 ; 3.34 ; and 2.99 on fresh bulbs for treatments A, B and C, respectively and $4.34,4.85$ and 4.31 on dry bulbs for treatments A, B and C, respectively. Technology package B was more profitable than $A$ as indicated by MBCR value of 9.36 and 3.56 for treatment $\mathrm{B}$ and $\mathrm{A}$, respectively. The breakeven point of both production and price of technology package B was $3.4 \mathrm{t} \mathrm{ha}^{-1}$ and $\mathrm{Rp} .8,553 \mathrm{~kg}^{-1}$, respectively.
\end{abstract}

\section{Introduction}

Garlic (Allium sativum L.) is a national strategic vegetable commodity, which is needed for household consumption and as a raw material for medicines and cosmetics [1,2]. In Indonesia, national demand for garlic continues to increase but national production is very limited. More than 90 percent of consumption was fulfilled from imports. In 2017, national consumption of garlic reached 475,750 tons, while national production was only 41,750 tons $(8.77 \%)$, so around 434,000 tons were imported from China [3]. The low national garlic production is not only caused by the decreasing harvest area, but its productivity is generally low. In 1995, the planted area of garlic reached 21,896 ha and then dropped drastically to 2,407 ha in 2016. According to the Directorate General of Horticulture [3],

\footnotetext{
* Corresponding author: mohnazamntb@gmail.com
} 
garlic production requires an area of 72,249 ha to achieve self-sufficiency, assuming an average productivity of $8.35 \mathrm{t} / \mathrm{ha}$ dried bulbs to obtain a production of 603,000 tons.

West Nusa Tenggara is one of the national garlic production centers outside Java. It is grown in Lombok Island, namely in Sembalun, East Lombok and in Sumbawa Island, namely in Soromandu, Bima Regency [3]. Garlic production centers in Java Island are located in Temanggung, Karanganyar, Tegal and Magetan. In the 1980s, Sembalun had reached the peak production of garlic, but currently the garlic harvested area have decreased. The decline of garlic planted areas in Sembalun was caused by several factors, including the lack of bulbs seed availability at the planting period, which cause seed price increase. Besides, farmers were less enthusiastic to grow the commodity due to import policies where imported garlic was abundant in traditional markets at harvest period with low prices.

To overcome this problem, it is necessary to build a garlic seed production system in West Nusa Tenggara which includes technical, economic aspects, trade channels, opportunities development and constraints. This study aim was to evaluate productivity and profitability of the garlic seed production with improved technology package in West Nusa Tenggara. The results of this study are expected to be a reference in expanding the garlic planting areas while increasing the production and stability of profitable garlic prices in West Nusa Tenggara.

\section{Materials and methods}

\subsection{Materials}

The research was conducted through a participatory on-farm research approach, involving farmers as cooperators on an area of 0.7 ha in Sembalun, East Lombok Regency from April to December 2019. The materials used in this study were: garlic bulb seeds, inorganic and organic fertilizers, pesticides, and Trichoderma.

\subsection{Methods}

\subsubsection{Experimental design}

Three technology packages were tested i.e. (A). national recommendation technology package [3]; (B). Site-specific recommendation technology package for garlic seed production (developed by Assessment Institute of Agricultural Technology, AIAT West Nusa Tenggara); and (C). Farmer practices technology package (indigenous technology). The experiment was laid out in a randomized completely block design with six replications [4]. The garlic variety was the Sangga Sembalun which was stored for 6 months before planting. The characteristics of three technology packages are presented in Table 1. 
Table 1. Characteristics of technology packages of garlic seed production in highland of Sembalun, West Nusa Tenggara, Indonesia.

\begin{tabular}{|c|c|c|c|}
\hline \multirow{2}{*}{$\begin{array}{c}\text { Components of } \\
\text { technology }\end{array}$} & \multicolumn{3}{|c|}{ Technology packages } \\
\hline & $\mathbf{A}$ & B & $\mathrm{C}$ \\
\hline $\begin{array}{l}\text { Land } \\
\text { preparation }\end{array}$ & 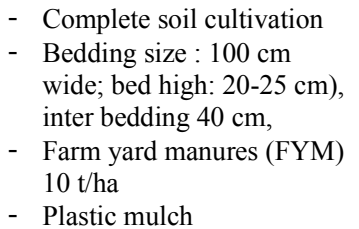 & $\begin{array}{ll}\text { - } & \text { Similar to A } \\
\text { - } & \text { Apply dolomit } 1 \mathrm{t} / \mathrm{ha} \\
\text { during soil cultivation. } \\
\text { - } \\
\text { FYM } 5 \mathrm{t}^{-} \mathrm{ha}^{-1} \\
\text { - } \\
\text { Adding Trichoderma as } \\
\text { tricho-compost }\end{array}$ & $\begin{array}{l}\text { Similar to A with no } \\
\text { compost and dolomit }\end{array}$ \\
\hline Seed & $\begin{array}{l}\text { Certified seed of sangga } \\
\text { sembalun variety }\end{array}$ & $\begin{array}{l}\text { Certified seed of sangga } \\
\text { sembalun variety }\end{array}$ & $\begin{array}{l}\text { Certified seed of sangga } \\
\text { sembalun variety }\end{array}$ \\
\hline Plant spacing & $10 \times 10 \mathrm{~cm}$ & $10 \times 10 \mathrm{~cm}$ & $10 \times 10 \mathrm{~cm}$ \\
\hline Fertilization & $\begin{array}{l}\text { FYM } 10 \text { t/ha, SP36: } 500 \\
\mathrm{~kg} / \mathrm{ha} \text {, Urea } 250 \mathrm{~kg} / \mathrm{ha}, \\
\text { Phonska Plus (NPK:15-15-15) } \\
650 \mathrm{~kg} / \mathrm{ha} \text { and ZA } 150 \mathrm{~kg} / \mathrm{ha}\end{array}$ & $\begin{array}{l}\text { FYM } 10 \text { t/ha, SP36: } 500 \\
\mathrm{~kg} / \mathrm{ha} \text {, Urea } 250 \mathrm{~kg} / \mathrm{ha} \\
\text { Phonska Plus (NPK: } 15-15- \\
\text { 15) } 650 \mathrm{~kg} / \mathrm{ha} \text { and ZA } 150 \\
\mathrm{~kg} / \mathrm{ha}\end{array}$ & $\begin{array}{l}\text { SP36: } 500 \mathrm{~kg} / \mathrm{ha} \text {, Urea } 250 \\
\mathrm{~kg} / \mathrm{ha}, \text { Phonska Plus } \\
(\mathrm{NPK}: 15-15-15) 650 \mathrm{~kg} / \mathrm{ha} \\
\text { and ZA } 150 \mathrm{~kg} / \mathrm{ha}\end{array}$ \\
\hline $\begin{array}{l}\text { Pest and dise- } \\
\text { ases control }\end{array}$ & $\begin{array}{l}\text { Using integrated pest and } \\
\text { diseases control }\end{array}$ & $\begin{array}{l}\text { Using integrated pest and } \\
\text { diseases control }\end{array}$ & $\begin{array}{l}\text { Using integrated pest and } \\
\text { diseases control }\end{array}$ \\
\hline Roughing & $\begin{array}{l}\text { Uprooting diseased plants or } \\
\text { abnormal growth according to } \\
\text { the identity of the variety and } \\
\text { leaving plants with normal and } \\
\text { uniform growth }\end{array}$ & $\begin{array}{l}\text { Uprooting diseased plants or } \\
\text { abnormal growth according } \\
\text { to the identity of the variety } \\
\text { and leaving plants with } \\
\text { normal and uniform growth }\end{array}$ & $\begin{array}{l}\text { Uprooting diseased plants or } \\
\text { abnormal growth according } \\
\text { to the identity of the variety } \\
\text { and leaving plants with } \\
\text { normal and uniform growth }\end{array}$ \\
\hline Harvesting & $\begin{array}{l}\text { Harvesting was done at } 95-120 \\
\text { DAP indicated by } 70-80 \% \\
\text { yellowing leaves and solid } \\
\text { bulbs. }\end{array}$ & $\begin{array}{l}\text { Harvesting was done at } 95- \\
120 \text { DAP indicated by } 70- \\
80 \% \text { yellowing leaves and } \\
\text { solid bulbs. }\end{array}$ & $\begin{array}{l}\text { Harvesting was done at } 95- \\
120 \text { DAP indicated by } 70- \\
80 \% \text { yellowing leaves and } \\
\text { solid bulbs. }\end{array}$ \\
\hline $\begin{array}{l}\text { Drying and } \\
\text { storing }\end{array}$ & $\begin{array}{l}\text { Harvested bulbs were sun } \\
\text { dried for } 1-2 \text { weeks and store } \\
\text { for 5-6 months }\end{array}$ & $\begin{array}{l}\text { Harvested bulbs were sun } \\
\text { dried for } 1-2 \text { weeks and store } \\
\text { for } 5-6 \text { months }\end{array}$ & $\begin{array}{l}\text { Harvested bulbs were sun } \\
\text { dried for } 1-2 \text { weeks and store } \\
\text { for 5-6 months }\end{array}$ \\
\hline
\end{tabular}

Post-harvest handling and seed storage followed methods described by Siahaan et al. [5], including: a) cleaning and sorting to separate good bulbs from young, damaged or rotten bulbs; b) drying the seeds under the sun for 1-2 weeks until they reach a weight loss of $40-50 \%$; c) the seeds were stored in for 4-6 months; d) the seeds are ready to be planted after the shoot point reaches $30-75 \%$ of the clove length.

\subsubsection{Statistical analysis}

Parameters measured in this experiment included data on farm input and output, yield, and financial analysis. Data were also collected through interviews, observations [6], farm record keeping (FRK), and focus group discussions (FGD). Data were analyzed statistically using analysis of variance (ANOVA) [7].

\subsubsection{Financial analysis of garlic seed production}

Economic data were analyzed based on cost and revenue structure analysis [8] using the formula:

$$
\mathrm{I}=\sum(Y . P y)-(X i . P x i)
$$

$\mathrm{I}=$ Income (Rp./ha)

$\mathrm{Y}=$ Production (yield) ton $/ \mathrm{ha}$

Py $=$ price yield $(\mathrm{Rp} . / \mathrm{ton})$

$\mathrm{Xi}=$ The type and amount of the $\mathrm{i}$ input used $(\mathrm{i}=1,2,3, \ldots . \mathrm{n})$ in each unit

Pxi $=$ The unit price of the i production input $(\mathrm{i}=1,2,3, \ldots \ldots \mathrm{n})$ in $\mathrm{Rp} . / \mathrm{unit}$ 
To find out the profit or production achievement position from the garlic seed production business, a break-even-point analysis (Break Event Point) was carried out for both the production break-even-point (TIP) and the price-break-even-point (TIH) with the formula [8]:

$$
\text { Production Break Event Point: } \frac{\sum X 1 P X i}{P q}
$$

$\sum \mathrm{XiPXi}$ is the total price of farming,

$\mathrm{Xi}$ is input type of- $\mathrm{i}(\mathrm{i}=1,2,3, \ldots, \mathrm{n})$

$\mathrm{Pq}$ is product price per unit $(\mathrm{kg})$

$$
\text { Price break event point: } \frac{\text { Total cost }}{\text { Yield }}
$$

The economic feasibility of the technology was analysed using Marginal Benefit-Cost Ratio (MBCR) using formulation:

$$
\mathrm{MBCR}=\frac{\text { Income }(B)-\text { Income }(P)}{\text { Total cost }(B)-\text { Total cost }(P)}
$$

$B=$ New Technology

$\mathrm{P}=$ Farmer Technology (existing)

A new technology is economically feasible if it has a minimum MBCR value of 2.0 [9]. The MBCR analysis was carried out with the assumption that the application of new technology requires higher costs than the costs needed to apply farmer technology.

\section{Results and discussion}

\subsection{Characteristics of the research area}

Sembalun Bumbung is one of six villages in Sembalun sub-district, East Lombok Regency with covered area of 5,797 ha $(26.70 \%)$ of the area of Sembalun sub-district and is located at an altitude of 1,177 $\mathrm{m}$ above sea level (asl). Sembalun sub-district has an area of 217.08 $\mathrm{km}^{2}$. Based on land use, Sembalun sub-district consisted of 3,908 ha of paddy fields, 548 ha of yards, 16,177 ha of dryland and 1,028 ha of other uses [10]. The average annual number of rainy days in Sembalun was 160 days and average annual rainfall for 40 years (19772017) was about $2,503 \mathrm{~mm} /$ year [11]. The distribution of average monthly rainfall in Sembalun Sub-district is presented in Figure 1. In general, wet season of Sembalun subdistrict commenced on October to May. During his period, farmers usually cultivate rice due to the abundance of rainfall. Planting time of garlic start on March, following rice harvested. Irrigation of water for cultivation garlic during March to May was adequate from rainfall source, and water irrigation for the rest of the months during the growth period of garlic was supplied through supplementary irrigation. It has reported that optimum yields of garlic may be reach with total irrigation water of $460 \mathrm{~mm}[12,13]$. 


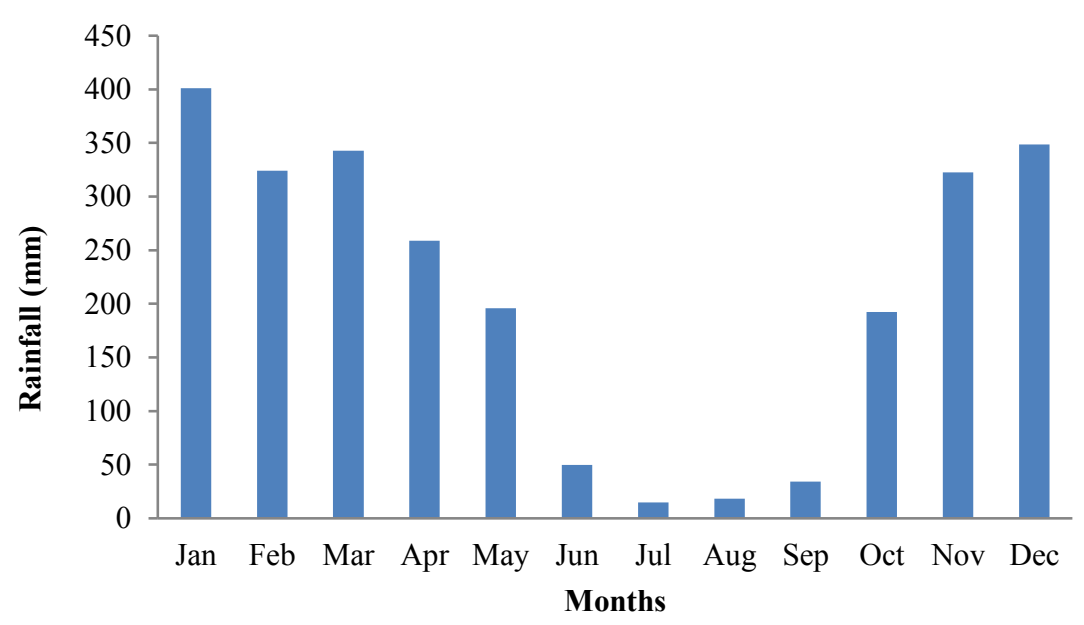

Fig.1. Average monthly rainfall of Sembalun Sub-district for 40 years (1977-2017).

Total population of the Sembalun Sub-district was 19,743 people, consisted of 9,518 men and 10,255 women with 5,812 households and an average household member of 3.4 people. Numbers of people who work in the agricultural sector were 4,258 farmers where some of them were 1,654 farm laborers, and 582 livestock farmers. Distribution of population who work in non-agricultural sector consisted of 94 people worked as traders and industry sectors, 70 people worked at transportation and 178 people for other sectors. Common horticultural commodities cultivated by farmers in Sembalun included garlic, shallots, strawberries, chilies, tomatoes, cabbage, lettuce, potatoes, carrots, and others.

There were 6 cooperating farmers who were involved in this experimental site, with an average age of farmers has classified as productive age, between 45-50 years with the number of family members between 3-5 people. The level of education varied from elementary to high school and the main source of income was from the agricultural sector.

Land ownership size of farmer was between $0.25-0.75$ ha for both in technical irrigated land and dry land. The soil at the study site has a moderate to high level of acidity ( $\mathrm{pH} 4-5$ ), sandy loam texture, and less than 2\%organic $\mathrm{C}$ content. Dolomite 1-2 $\mathrm{t} \mathrm{ha}^{-1}$ and compost 5-10 $\mathrm{t} \mathrm{ha}^{-1}$ may be applied in order to increase $\mathrm{pH}$ value so that soil fertility can be increased.

\subsection{Productivity of garlic at various technology packages}

The fresh bulbs yield of garlic at various technology packages is presented in Table 2 . Table 2 shows that the highest fresh yield of the Sangga Sembalun garlic was found at technology package A with an average yield of $42.19 \mathrm{t} \mathrm{ha}^{-1}$, followed by technology package B with average yield of $38.99 \mathrm{t} \mathrm{ha}^{-1}$ although this was not significantly different and the lowest garlic yield was found at farmer practices (treatment $\mathrm{C}$ ) with average yield of $31.24 \mathrm{t} \mathrm{ha}^{-1}$. The difference of garlic yield caused by treatments may be due to differences in the dose of compost fertilizer where the technology package A applied $10 \mathrm{t}$ $\mathrm{ha}^{-1}$ of compost while technology package B was $5 \mathrm{t} \mathrm{ha}^{-1}$ and there was no compost applied in farmers practice or treatment C. Suwandi [14] reported that the soils in the Sembalun area have a low organic matter content as a result of the continuous use of high-intensity inorganic fertilizers for vegetable production. Thus the application of organic fertilizer is very important to improve the soil structure, as well as soil fertility in the area [15]. 
Table 2. Productivity of fresh garlic of the Sangga Sembalun variety at various technology packages in tropical highland of Sembalun, Indonesia $\left(\mathrm{t} \mathrm{ha}^{-1}\right)$.

\begin{tabular}{|c|c|c|c|c|c|c|c|}
\hline \multirow{2}{*}{ Treatments } & \multicolumn{6}{|c|}{ Replication $\left(\mathrm{t} \mathrm{ha}^{-1}\right)$ fresh bulbs } & \multirow{2}{*}{ Average } \\
\hline & 1 & 2 & 3 & 4 & 5 & 6 & \\
\hline A & 43.440 & 37.814 & 41.034 & 38.313 & 47.922 & 44.618 & $42.190 b$ \\
\hline B & 36.143 & 38.906 & 37.350 & 35.933 & 44.952 & 40.633 & $38.986 \boldsymbol{b}$ \\
\hline $\mathrm{C}$ & 30.296 & 33.087 & 30.259 & 28.975 & 29.710 & 35.138 & $31.244 a$ \\
\hline
\end{tabular}

Note: Numbers followed by the same letter in the same column show no significant difference at the $5 \%$ level $(\mathrm{p}=0.05)$

In general, the results achieved in this study were higher than those obtained by Hilman and Noordiyati [16] where fresh weight of garlic in irrigated highlands with NPK balance fertilizer was 16-20 $\mathrm{t} \mathrm{ha}^{-1}$, and were also higher than others results of study $[17,18]$. However, these differences may be due to the differences in the varieties of garlic grown and technology packages applied. Hadiawati and Nazam [19] reported that yield of garlic increased as spacing size decreased although bulbs size was also decreased. Moreover, Jiku et al. [20] reported that the maximum total yield and size of garlic bulb were obtained with potassium application at $200 \mathrm{~kg} \mathrm{ha}^{-1}$ and similar trend of results was also obtained by ElBassiony [21].

The results of observations after the drying and storage for 12 weeks showed that there was a varies decrease in the weight of garlic bulbs from wet weight to dry weight (seed weight) due to treatments $\mathrm{A}, \mathrm{B}$ and $\mathrm{C}$, as presented in Table 3.

Table 3. Productivity of dry garlic bulbs of the Sangga Sembalun variety at various technology packages in Sembalun tropical highland of Sembalun, Indonesia $\left(\mathrm{t} \mathrm{ha}^{-1}\right)$

\begin{tabular}{|c|c|c|c|c|c|c|c|}
\hline \multirow{2}{*}{ Treatments } & \multicolumn{6}{|c|}{ Replication (t ha $\left.{ }^{-1}\right)$ dry bulbs } & \multirow{2}{*}{ Average } \\
\hline & 1 & 2 & 3 & 4 & 5 & 6 & \\
\hline $\mathrm{A}$ & 15.508 & 13.500 & 14.649 & 13.678 & 17.108 & 15.929 & $15.062 b$ \\
\hline $\mathrm{B}$ & 14.746 & 15.874 & 15.239 & 14.661 & 18.340 & 16.578 & $15.906 \boldsymbol{b}$ \\
\hline $\mathrm{C}$ & 12.421 & 13.566 & 12.406 & 11.880 & 12.181 & 14.406 & $12.810 a$ \\
\hline
\end{tabular}

Note: Numbers followed by the same letter in the same column show no significant difference at the $5 \%$ level $(\mathrm{p}=0.05)$.

Table 2 and Table 3 indicate that the highest water content of dry bulbs of garlic seed was found at package A for $62.1 \%$, followed by package B for $59.2 \%$ and the lowest was package $\mathrm{C}$ for $59 \%$. Bayat et al. [22] reported that ideal water content of garlic seed for storing was in the range of $62 \%-64 \%$. The results of this experiment indicated that water content lost was in the range of recommendation for technology package A while treatments $\mathrm{B}$ and $\mathrm{C}$ were just below of the range. Based on the percentage loss, the dry weight of the Sangga Sembalun garlic seed bulbs after a 12-week drying/storage period showed that the highest yield was found at technology package B, although this was not significantly difference with technology package A but it was significantly different with technology package $\mathrm{C}$. The garlic yield of this study were higher than that the potential yield of Sangga Sembalun variety reported by the Directorate General of Horticulture [3] where garlic yield achieved in 2017 was 9-10 $\mathrm{t} \mathrm{ha}^{-1}$. Thus, the application of technology package $\mathrm{B}$ gave a higher seed yield compared to the application of technology packages $\mathrm{A}$ and $\mathrm{C}$.

\subsection{Cost structure and farming income of seed production}

To find out the profitability and feasibility of the garlic seed production in Sembalun, financial analysis was taken using a cost and income structure approach descripted by 
Hendayana [8]. The main purpose of the cost and revenue structure analysis was to determine the proportion of each type of expenditure used to purchase inputs in a certain time, volume and area. The structure of costs and revenues for the production of garlic seeds in Sembalun, both in the form of fresh bulbs and dry bulbs are presented in Table 4.

Table 4. Cost structure and financial analysis of garlic seed production in the Sembalun highlands, East Lombok $\left(\mathrm{ha}^{-1}\right)$

\begin{tabular}{|c|c|c|c|}
\hline \multirow{2}{*}{ Cost components and production } & \multicolumn{3}{|c|}{ Technology packages } \\
\hline & $\mathbf{A}$ & $\mathbf{B}$ & C (Eksisting) \\
\hline \multicolumn{4}{|l|}{ 1. Input production } \\
\hline a. Seed @Rp.40.000/kg & 40.000 .000 & 40.000 .000 & 40.000 .000 \\
\hline b. Lime @ Rp.1.400/kg & 1.400 .000 & 1.400 .000 & - \\
\hline c. Compost @ Rp.1.000/kg & 10.000 .000 & 5.000 .000 & - \\
\hline d. Inorganic fertilizer (packages) & 9.325 .000 & 9.325 .000 & 9.325 .000 \\
\hline e. Mulch @ Rp.600.000/roll & 8.400 .000 & 8.400 .000 & 8.400 .000 \\
\hline f. pesticide(package) & 5.000 .000 & 5.000 .000 & 5.000 .000 \\
\hline Total (a-f) & 74.125 .000 & 69.125 .000 & 62.725 .000 \\
\hline \multicolumn{4}{|l|}{ 2. Labour } \\
\hline a. Land Preparation (1 ha) & 5.500 .000 & 5.500 .000 & 5.500 .000 \\
\hline b. Liming & 500.000 & 500.000 & - \\
\hline c. Basalt fertilizer & 500.000 & 500.000 & 500.000 \\
\hline d. Installing mulch 14 Roll & 2.120 .000 & 2.120 .000 & 2.120 .000 \\
\hline e. Seedling (1 ha) & 1.500 .000 & 1.500 .000 & 1.500 .000 \\
\hline f. Fertilizers (1-4 times) & 1.000 .000 & 1.000 .000 & 1.000 .000 \\
\hline $\begin{array}{l}\text { g. Plant maintenance (irrigation, } \\
\text { weeding, pesticide application) }\end{array}$ & 2.500 .000 & 2.500 .000 & 2.500 .000 \\
\hline h. Harvesting & 25.314 .000 & 23.391 .600 & 18.746 .400 \\
\hline Total $2(\mathrm{a}-\mathrm{h})$ & 38.934 .000 & 37.011 .600 & 32.366 .400 \\
\hline $\begin{array}{l}\text { 3. Capital interest } 10 \%(1+2) \mathrm{Rp} \text {. } \\
\text { Season }^{-1}\end{array}$ & 11.305 .900 & 10.613 .660 & 9.509 .140 \\
\hline 4. Total Cost $(1+2+3)$ Rp.ha ${ }^{-1}$ & 124.364 .900 & 116.750 .260 & 104.600 .540 \\
\hline 5. Fresh bulb Yield $\left(\mathrm{t} \mathrm{ha}^{-1}\right)$ & 42,190 & 38,986 & 31,244 \\
\hline 6. Fresh yield values Rp.ha ${ }^{-1}$ & 421.900 .000 & 389.860 .000 & 312.440 .000 \\
\hline 7. Revenue (Rp. $\left.\mathrm{h}^{-1}\right)$ & 297.535 .100 & 273.109 .740 & 207.839 .460 \\
\hline 8. $\mathrm{R} / \mathrm{C}$ ratio (in fresh) & 3,39 & 3,34 & 2,99 \\
\hline \multicolumn{4}{|l|}{ 9. Seed storing for 12 week } \\
\hline a. Bambo for loft & 7.000 .000 & 7.000 .000 & 7.000 .000 \\
\hline b. Making loft & 2.000 .000 & 2.000 .000 & 2.000 .000 \\
\hline c. tarpaulin & 1.000 .000 & 1.000 .000 & 1.000 .000 \\
\hline d. Sorting of seed and storage & 2.000 .000 & 2.000 .000 & 2.000 .000 \\
\hline e. Rope & 1.000 .000 & 1.000 .000 & 1.000 .000 \\
\hline Total $9(\mathrm{a}-\mathrm{e}) \mathrm{Rp}$. & 13.000 .000 & 13.000 .000 & 13.000 .000 \\
\hline 10. Capital interest $10 \%$ & 1.300 .000 & 1.300 .000 & 1.300 .000 \\
\hline 11. Seed certification & 5.000 .000 & 5.000 .000 & 5.000 .000 \\
\hline 12. Total cost $(4+9+10+11)$ Rp.ha $^{-1}$ & 143.664 .900 & 136.050 .260 & 123.900 .540 \\
\hline 13. Dry yield bulb t ha ${ }^{-1}$ & 15,062 & 15,906 & 12,810 \\
\hline 14. Value of dry yield bulb $\mathrm{Rp} \mathrm{ha}^{-1}$ & 602.480 .000 & 636.240 .000 & 512.400 .000 \\
\hline 15. Revenue (14-12) & 463.815 .100 & 505.189 .740 & 393.499 .460 \\
\hline 16. $\mathrm{R} / \mathrm{C}$ ratio seed $(14 / 12)$ & 4,34 & 4,85 & 4,31 \\
\hline
\end{tabular}

Table 4 shows that the business of garlic seeds production in the highlands of Sembalun if the prospective seeds are sold in the form of wet bulbs provides a profit for each package A, B, and C of Rp. 297,535,100, Rp. 273,109,740 and Rp. 207,839,460. with consecutive 
$\mathrm{R} / \mathrm{C}$ of $3.39 ; 3.34$ and 2.99 , respectively. Thus, the business of producing garlic seeds by selling wet production provides an advantage so that it is feasible to cultivate. Based on the financing structure, it can be seen that the highest proportion of costs was the cost of production facilities with an average $(59.59 \%)$, followed by the average labor cost $(31.32 \%)$. The costs of production facilities were mostly for the purchase of seeds $(58.53 \%)$ followed by chemical fertilizers (13.65\%), and plastic mulch (12.29\%). The rest was for the purchase of dolomite, compost and pesticide.

If the garlic seeds were sold in the form of dry seeds with 12 weeks of storage, the profit for each technology packages of A, B and C were IDR Rp. 463,815,100 ha ${ }^{-1}$; Rp. $505,189,740 \mathrm{ha}^{-1}$ and Rp.393,499,460 ha-1 with $\mathrm{R} / \mathrm{C}$ ratio of 4,34, 4.85 and 4.31, respectively. Based on these data, the garlic seed production business result benefits with $\mathrm{R} / \mathrm{C}$ value was greater than 1 which was feasible to cultivate. Utami et al. [23] reported that garlic cultivation in rainfed area of Sembalun was benefit to farmers as indicated by the value of $\mathrm{R} / \mathrm{C}$ ratio that was higher than 1 .

\subsection{Feasibility of technology introduced}

The feasibility of a new technology is measured based on an indicator of how much benefit (additional profit) is obtained with the additional costs that must be sacrificed as a result of the application of the new technology which is known as the marginal benefit cost ratio (MBCR). If the value of the benefits obtained is greater than 2, it can be said that the new technology is feasible to be developed [24]. The results of the MBCR analysis of the application of new technology in the garlic seed production in highland of Sembalun are presented in Table 5.

Table 5. Marginal Benefit Cost Ratio value (MBCR) of the application of new technology in the garlic seed production business in Sembalun, East Lombok $\left(\mathrm{ha}^{-1}\right)$ in 2019.

\begin{tabular}{|c|c|c|}
\hline Description & A Package & B Package \\
\hline 1. Benefit from new technology Rp. $\mathrm{Ha}^{-1}$ & 463.815 .100 & 505.189 .740 \\
\hline 2. Benefit of farmer technology (C package) $\mathrm{Rp} . \mathrm{Ha}^{-1}$ & 393.499 .460 & 393.499 .460 \\
\hline 3. Difference benefit (1-2) Rp. $\mathrm{Ha}^{-1}$ & 70.315 .640 & 111.690 .280 \\
\hline 4. Total cost from new technology $\mathrm{Rp} . \mathrm{Ha}^{-1}$ & 143.664 .900 & 136.050 .260 \\
\hline 5. Total cost from farmer technology Rp. $\mathrm{Ha}^{-1}$ & 123.900 .540 & 123.900 .540 \\
\hline 6. Difference total cost (4-5) Rp. $\mathrm{Ha}^{-1}$ & 19.764 .360 & 12.149 .720 \\
\hline 7. Value of MBCR (3/6) & 3,56 & 9,19 \\
\hline
\end{tabular}

Based on the results of the marginal benefit cost ratio analysis (Table 5), each value is 3.56 for the application of technology package A and 9.36 for the application of technology package $\mathrm{B}$. This means that both technology packages are economically feasible to develop and the application of technology package B was more efficient compared to the technology package A.

\subsection{Break-even point of garlic seed production}

The results of the analysis of the break-even point or return of principal for both production and prices are presented in Table 6 . Table 6 shows the minimum production that must be obtained so that there is no loss but does not provide the benefit for the application of technology package A is $3.59 \mathrm{t} \mathrm{ha}^{-1}$, for the application of technology package B is $3.4 \mathrm{tha}^{-1}$ and if applying technology package $\mathrm{C}$ is $3.09 \mathrm{t} \mathrm{ha}^{-1}$. The price break-even point for seed production obtained for Technology package A, B and C were Rp. $9,538 \mathrm{~kg}^{-1}, \mathrm{Rp} .8,553 \mathrm{~kg}^{-}$ ${ }^{1}$ Rp. $9,672 \mathrm{~kg}^{-1}$, respectively. 
Table 6. Break-even point of production and business price of garlic seed production of Sangga Sembalun variety in Sembalun, East Lombok, NTB.

\begin{tabular}{|l|r|r|r|}
\hline \multicolumn{1}{|c|}{ Description } & A Package & \multicolumn{1}{c|}{ B Package } & C Package \\
\hline 1. Total cost (Rp) & $143,664,900$ & $136,050,260$ & $123,900,540$ \\
\hline 2. Seed price (ton) & $40,000,000$ & $40,000,000$ & $40,000,000$ \\
\hline 3. Yield break-even point (1/2) ton & 3.592 & 3.401 & 3.098 \\
\hline 4. Seed production (kg) & 15,062 & 15,906 & 12,810 \\
\hline 5. Price break-even point (1/4) Rp/kg & 9.538 & 8.553 & 9.672 \\
\hline
\end{tabular}

\subsection{Farming efficiency of garlic seed production}

Based on the analysis results of the cost and income structure (Table 4), it is shown that the garlic seed production in Sembalun highland has reached a high level of efficiency, both technically and economically aspects, indicated by the $\mathrm{R} / \mathrm{C}$ value which is greater than 1 and MBCR value was greater than 2. Efficiency is the result of a comparison between physical output and physical input. The higher the ratio of output to input, the higher the level of efficiency achieved. Efficiency is also described as the achievement of maximum output from the use of certain resources. If the output produced is greater than the resources used, the higher the level of efficiency achieved.

Efficiency is divided into 2 types, namely technical efficiency and economic efficiency [24]. Technical efficiency requires a production process that can utilize fewer inputs to produce the same amount of output. While the concept of economic efficiency is to minimize costs, meaning that a production process will be economically efficient at an output level if there is no other process that can produce similar output at a lower cost. It can also be said that the addition of a number of inputs can increase the output which is larger and more profitable.

\section{Conclusions}

Garlic seed production of Sangga Sembalun variety was influenced by cultivation technique. Fresh yield of the Sangga Sembalun garlic variety was not significantly different for packages A and B, but it was significantly different with package C. This trend of garlic yield was consistently similar after seed stored for 12 weeks. Financial analysis indicated that garlic seed production was profitable for both fresh and dry bases with value of $\mathrm{R} / \mathrm{C}$ ratio of garlic on dry bases was $4.34,4.85$ and 4.31 for treatments $\mathrm{A}, \mathrm{B}$ and $\mathrm{C}$, respectively. Package $\mathrm{B}$ technology was more profitable than package A as indicated by MBCR.

Acknowledgment. We thank the Indonesian Agency for Agricultural Research and Development for funding this research through the collaboration of research, assessment and development agricultural strategic program. (KP4S). We also thank Mr. Rasyid Ridho for helping in crop management and observations in the field. Titin Sugianti, Lia Hadiawati, Moh. Nazam and Ahmad Suriadi are contribute equally in the experimental process and in writing this paper.

\section{References}

1. D. Zohary, M. Hopf, Domestication of plants in the Old World (Oxford University press, 2002)

2. V. Guercio, T. Federica, L. Vecchia, C. Galeone, C. Tavani, Alessandra, Mol. Nutr. Food Res. 60, 1, 212-222 (2016) 
3. D. Hortikultura, Pengembangan bawang merah nasional (Kementerian Pertanian, 2017)

4. K.A. Gomez, A.A. Gomez, Statistical Procedures for Agricultural Research, 2ed ed. (John Wiley and Sons Inc, New York,1984)

5. S.P. Siahaan, T. Hidayat, S.I. Kallaku, A. Arif, J. Keteknikan Pertanian. 8, 1, 29-38, (2020)

6. N. Muhajir, Qualitative Research Methods (Fourth Edi, Yogyakarta, 2000)

7. STAR, Statistical Tool for Agricultural Reserch (STAR) 2.0.1. (International Rice Research Institute, Los Banos, 2019)

8. R. Hendayana, Analisis Data Pengkajian (IAARD Press, Jakarta, 2016)

9. G.R. Banta, S.K. Jayasuriya, Basic Procedures for Agroeconomic Research (International Rice Research Institute, Manila, Philippines, 1991)

10. BPS NTB, Nusa Tenggara Barat Dalam Angka (Badan Pusat Statistik, Mataram, 2017)

11. L. R. Oldeman, I. Las, Muladi, The Agroclimatic Map of Kalimantan, Irian Jaya, and Bali, West and East Nusa Tenggara (CRIA, Bogor, 1980)

12. C.F. Cortes, F.M.S. Olalla, R. Urrea, Agric. Water Manag. 59, 155-167 (2003)

13. B. Hanson, D. May, R. Voss, M. Cantwell, R. Rice, Agric. Water Manag. 58, 29-43, (2003)

14. Suwandi, Pengaruh pengapuran dan pemberian pupuk kandang terhadap pertumbuhan dan hasil bawang putih pada tanah Latosol Merah Kuning (Lembang, Jawa Barat, 1990)

15. F.J. Stevenson, Humus chemistry. Genesis, composition, reactions (John Wiley and Sons Inc., New York, Chichester, Brisbane, Toronto, Singapore, 1982)

16. Y. Hilman, I. Noordiyati, Bul. Penel. Hort. XVI, 1, 48-53, (1998)

17. A. Asandhi, N. Gunadi, Bul. Penel. Hort. XII, 2, 4-10, (1986)

18. N. Gunadi, Suwandi, Y. Hilman, Bul. Penel. Hort. XVI, 4, 5-13, (1988)

19. L. Hadiawati, M. Nazam, Effect of spacing on growth and yield of Sangga Sembalun garlic variety of Sembalun Highland West Lombok, in The 7th International Conference on Sustainable Agriculture and Environment, 012065, doi: doi:10.1088/1755-1315/637/1/012065, (2021)

20. M.A.S. Jiku, M. Alimuzzaman, A. Singha, M.A. Rahaman, R.K. Ganapati, M.A. Alam, S.R. Sinha, Bull. Natl. Res. Cent. 44, 1, (2020)

21. A.M. El-Bassiony, J. App. Sci. Res. 2, 10, 780-785 (2006)

22. F. Bayat, S. Rezvani, A. Nosrati, Acta Hortic. 877, 869-875 (2010)

23. U.S. Kusumaputri, Mardiana, H. Nani, S. Titin, M.M. Faesal, Darwis, H.B. Nurul, Russ. J. Agric. Sci. 8, 104, 212-219 (2020)

24. J.P. Gittinger, Economic Analysis of Agricultural Projects (John Hopkins University Press, Jakarta, 1986) 